\title{
JAG2 wt Allele
}

National Cancer Institute

\section{Source}

National Cancer Institute. JAG2 wt Allele. NCI Thesaurus. Code C84308.

Human JAG2 wild-type allele is located in the vicinity of $14 \mathrm{q} 32$ and is approximately $27 \mathrm{~kb}$ in length. This allele, which encodes protein jagged-2, is involved in the regulation of cell migration, cell proliferation, cell cycle progression and signal transduction. 